\title{
Teologi og samfundsstudier
}

\author{
Lektor ph.d. \\ Bo Kristian Holm
}

Miriam Frenkel og Yaacov Lev (red.): Charity and Giving in Monotheistic Religions. Studien zur Geschichte und Kultur des islamischen Orients. Beihefte zur Zeitschrift "Der Islam". Neue Folge 22. Berlin - New York: Walter de Gruyter 2009. XVI + 413 s. (4 ill.). € 99,95.

Peter Berger, Grace Davie og Effie Fokas: Religiøse USA - sekulare Europa? Et tema og variationer. Oversat af Gerd Have og Allan Rosengren. København: Forlaget Anis 2010. 208 s. Kr. 249.

Nils Gunder Hansen, Jørn Henrik Petersen og Klaus Petersen (red.): I himlen således også på jorden? Odense: Syddansk Universitetsforlag 2010. 243 s. Kr. 248.

Abstract: This review deals with three differing studies on the relation between religion and social formation. The focus of Frenkel and Lev's Charity and Giving in Monotheistic Religions is on Islam, Judaism and Christianity in antique and medieval cultures, arguing that the monotheistic religions virtually agree in their understanding of charity and almsgiving. Berger, Davie and Fokas' Religious America, secular Europe? offers a profound analysis of the relation between religion and modernity in contemporary society. I himlen således også på jorden? (On earth as in heaven?) by Hansen, Petersen og Petersen (eds.) examines the claim of a tight connection between Lutheranism and the Nordic welfare state. All three volumes deal with the social doctrine inherent in religion, but it is argued that, at least when it comes to the Lutheran tradition, theology cannot be seen as just having a social doctrine, since the doctrine of justification can be seen as being a social doctrine in itself. This vital aspect should not be neglected while approaching the complex question of the role of religion in the formation of societies.

Key words: Theology - social studies - charity - giving - monotheistic religions - USA - Europe - modern religiosity - secularization - welfare state.

Forholdet mellem teologi og samfundsudvikling er et voksende forskningsfelt og det med god grund. Disse tre værker griber dette brede felt meget forskelligt an. Charity and Giving in Monotheistic Religions 
samler en række bidrag fra en international forskergruppe med fokus på velgørenhed og fromhed i senantikken og middelalderen. De to øvrige bøger behandler den vestlige verden i dag. Religiøse USA sekulare Europa? vil nuancere titlens stereotype billede af den transatlantiske forskel. I I himlen således også på jorden forsøger en række bidragydere at besvare spørgsmålet om lutherdommens indflydelse på dannelsen af den danske velfærdsstat.

Den oplagte sammenkobling af teologi og samfundsstudier har i lang tid været overset, hvad Sigrun Kahl har dokumenteret i en meget læsværdig artikel om overlappende grænser mellem forskellige kristne konfessionstyper og organiseringen af socialforsorg. Hun påpeger, hvordan de forskellige kristne konfessioners "sociale doktriner" må medtænkes i forståelsen af velfærdsstaternes forskellige udformning. ${ }^{1}$ Frenkel og Levs sammenligning af velgørenhed og almisser i antikken og middelalderen inden for jødedom, kristendom og islam kan læses som et forsøg i samme boldgade, men med hovedvægt på konkrete historiske eksempler. Det er der kommet en spændende bog ud af, først og fremmest på grund af disse mange eksempler.

Bogen er delt i tre dele: første del omhandler kristendommen i senantikken og den tidlige middelalder, de to sidste dele islam og jødedom i middelalderen. En velskrevet introduktion forsøger at give det samlende overblik, som de enkelte bidrag nødvendigvis må mangle. Man ender dog med at savne en samlende analyse, der i lighed med Sigrun Kahl overvejer forbindelser mellem teologiske forskelle i forståelsen af den monoteistiske Gud og forskelle i forståelsen af velgørenhed i de tre monoteistiske kulturer. Dermed har man undgået et muligt ømtåleligt emne, hvilket er forståeligt, men også ærgerligt. Bogen kan dog stå alene uden, for den giver et detaljeret indblik $i$ antikkens kristne og middelalderens jødiske og islamiske velgørenhed. En egentlig sammenligning ville dog have kunnet bidrage med nyt til den store diskussion om gave-givningens rolle i religion og teologi. Bogens bidrag argumenterer dog overbevisende for en række kontinuiteter på tværs af religion og tid. Fx viser Johannes Pahlitzsch, hvordan stiftelser har fungeret kontinuitetsbevarende under religiøse omvæltninger, hvor stiftelser indstiftet $i$ en religion ofte lever videre $i$ en anden. Undtaget er her overgangen fra kristendom til islam, hvor stiftelserne i stedet har inspireret dannelse af islamiske waqf.

Den ene af redaktørerne, Yaccov Lev, forsøger i "Charity and Gift Giving in Medieval Islam" at give en form for sammenligning. Han

1 Sigrun Kahl, "The Religious Roots of Modern Poverty Policy: Catholic, Lutheran, and Reformed Protestant Traditions Compared", Archives of European Sociology XLVI (2005), 91-125. Se også fx K. van Kersbergen og P. Manow, Religion, Class Coalitions and Welfare State Regimes (Cambridge: Cambridge University Press 2009). 
ser et fællestræk i synet på velgørenhed som forløsende. Først med protestantismens adskillelse af sammenhængen mellem velgørenhed og frelse sker der en ændring i forståelsen af monoteistisk velgørenhed. En lignende udvikling kan Lev hverken finde i jødedom eller i islam.

Den fælles monoteistiske velgørenheds-"økonomi" adskiller sig ifølge Lev fra den Mauss'ske gavegiving, fordi velgørenheden er drevet af den enkeltes stræben efter frelse og derfor er løsrevet fra jordisk gaveudveksling. I den monoteistiske velgørenhedsøkonomi får den jordiske modtager alene instrumentel funktion, for den egentlige udveksling sker mellem giver-agenten og den monoteistiske gud. Dette er såvel giver som modtager imidlertid i vid udstrækning fuldstændigt på det rene med (259f). Lev kommer med sit tilløb til en komparativ analyse imidlertid indirekte til at underbygge et klassisk luthersk syn på forståelsen af forholdet mellem reformatorisk og ikkereformatorisk teologi. Her synes at være mere at sige. Fx forekommer det umagen værd at tematisere, om det overhovedet spiller nogen rolle, om den Gud, der "udveksles" med, forstås strengt monoteistisk eller trinitarisk og dermed i en eller anden forstand også "socialt". Her er det et problem, at behandlingen af den kristne tradition med Eliana Magnanis "Almsgiving, Donatio Pro Anima and Eucharistic Offering in the Early Middle Ages of Western Europe (4th - 9th Century)" netop stopper så tidligt og ikke får middelalderens udvikling af trinitetstanken med.

Bogen har dog gode bidrag om den tidlige kristendom. Claudia Rapps "Charity and Piety as Episcopal and Imperial Virtues in Late Antiquity" udmærker sig fx gennem analysen af sammenhængen mellem Guds filantropi og det kristne herskerideal, der i høj grad viderefører sejlivede stoiske træk, som i parentes bemærket også lever videre i den reformatoriske tradition. I senantikken bliver konsekvensen, at synet på episkopal og verdslig magt smelter sammen (87). Også dette synes i nogen grad at gentage sig i bl.a. Melanchthons syn på fyrstens rolle. ${ }^{2}$ Her kan der utvivlsomt gøres interessante videre studier.

Et eksempel på velunderbygget komparativ analyse findes i Peter Berger, Grace Davie og Effie Fokas' bog Religious America, Secular Europe?, der i 2010 udkom i dansk oversættelse. Bogen vil læses som en fortsættelse af Grace Davies' Europe: The Exceptional Case. Parameters of Faith in the Modern World fra 2002. Dens pointer er

2 Den bedste oversigt over udviklingen i Melanchthons syn på fyrstens rolle findes i James M. Estes, Peace, Order and the Glory of God. Secular Authority and the Church in the Thought of Luther and Melanchthon, 1518-1559 (Leiden: Brill 2005). 
uomgængelige for enhver, der beskæftiger sig med kirkens og religionens rolle i den vestlige verden og med den sekulariseringstese, som i de senere år er blevet voldsomt kritiseret. Bogen placerer sig i det felt, hvor senest Francis Fukuyama har markeret sig. ${ }^{3}$ Modernitet er på ingen måde et entydigt fænomen, og den religionsløse udgave derfor blot én modernitetsform. Ikke kun globalt finder man mange modernitetsstrømninger, også inden for den euro-amerikanske kultursfære har moderniteten mange former med rod i vidt forskellige oplysningstraditioner.

Bogens analyse af religionens status i Nordeuropa er mere forfinet end den, man finder hos den amerikanske religionssociolog Phil Zuckerman, der ser en nær sammenhæng mellem Danmark som "perfekt samfund" og den danske religionsløshed. ${ }^{4}$ Faktisk ligner Berger, Davies og Fokas' forståelse af forholdet mellem europæeren og kirken den forståelse, som Søren Krarup repræsenterer, når han beskriver den almindelige folkekirkedansker som en, der om nødvendigt vil forsvare kirken, hvis den trues, trods sine kun yderst lejlighedsvise besøg i den. ${ }^{5}$ Dette understøttes i nogen grad af Berger, Davie og Fokas, der forstår denne lejlighedskirkegænger i forlængelse af Davie under overskriften "belonging without believing". Det betyder, at et positivt forhold til kirken ikke med nødvendighed implicerer nogen tradérbar viden om samme kirke. Dermed bliver det et spørgsmål, om og i givet fald hvordan kristendommen gives videre til næste generation.

I større skala beskæftiger bogen sig med forholdet mellem religion og samfundsformation, herunder forståelsen af statens ansvar for social velfærd. Bogen konkluderer, at den "stat, der har ansvaret for velfærden i Europa ... i sig selv [er] en europæisk konstruktion" (122). Hvor velfærd i Europa i vid udstrækning opfattes som en statslig opgave, opfattes det af mange i USA som en kirkelig opgave. Bogen peger næsten profetisk på, at den europæiske situation på ingen måde er statisk, og at økonomisk tilbagegang kan svække statens mulighed for at levere velfærdsydelser, hvorfor det ikke er utænkeligt, at man i Europa vil opleve en vækst i trosbaserede initiativer og en opblødning af grænsen mellem statstilbud og religiøse initiativer (129).

Forholdet mellem religion og samfundsformation er komplekst, og kompleksiteten angår både spørgsmålet om sammenhængen mellem religion og kulturel udvikling $i$ et historisk perspektiv og spørgsmålet om, hvordan religion og samfund vil påvirke hinanden i fremtiden. Antager man, at velfærdsstaten bl.a. bygger på en bestemt reli-

3 Francis Fukuyama, The Origins of Political Order (New York: Farrar, Straus and Giroux 2011).

4 Phil Zuckerman, Samfund uden Gud (Aarhus: Forlaget Univers 2008).

5 Cf. Søren Krarup, Kristendom og danskhed (Aarhus: Hovedland 2001), 80f. 
giøst formet kulturel tradition, er det uklart, hvad der vil ske, hvis denne tradition forsvinder. I bogen konfronterer forfatterne Richard Dawkins' påstand om, at religion ødelægger alt. Med henvisning til Danièle Hervieu-Légers studier af religiøse erindringskæders kollaps ${ }^{6}$ spørger de om, hvad der vil ske, hvis erindringen eller traditionen eroderer. De finder ikke Dawkins' forestilling om en velinformeret, sekulær rationalisme for mere sandsynlig end en udvikling hen imod "en langt mere sammensat, skiftende og til tider følelsesladet pakke af religiøse identiteter - delvis inden for og delvis uden for de historiske kirker" (84).

I bogen I himlen således også på jorden? forsøger en række bidragydere i sammenhæng med projektet "Dansk Velfærdshistorie" ved Syddansk Universitet at efterprøve tesen om, at den lutherske tradition er en væsentlig forudsætning for udviklingen af den danske velfærdsstat. Bogen lægger sig forlængelse af Sigrun Kahls hævdelse af, at de kristne konfessioners "sociale doktriner" må medtænkes i forståelsen af den socialpolitiske udvikling (12f), men tager også udgangspunkt i det forhold, at hidtidig forskning fra bl.a. Norge langt fra understøtter tesen. Kirkefolket er lige så delt som alle andre. Det rejser fra begyndelsen et problem: "Hvordan forener man en række forskeres påstand om velfærdsstaten som et barn af et evangelisk-luthersk syn med det forhold, at mange kirkefolk i deres egen forståelse så velfærdsstaten som en tvivlsom samfundsform, der blev mødt med skepsis - eller uden sammenhæng med forkyndelsen?” (17).

Udgiverne gør i deres indledning meget ud af at redegøre for de metodiske problemer, der knytter sig til undersøgelsen, men begrænser samtidigt bogens rækkevidde ved at koncentrere den om danske kirkefolks syn på velfærdsstaten.

Udgivernes egen konklusion er, at man måske ud af bidragene kan læse en lunken tilslutning til tesen om sammenhæng mellem Lutherdom og velfærdsstat, men ikke mere. En så usikker konklusion er naturligvis ikke tilfredsstillende, hverken for læserne eller udgiverne, hvilket ikke betyder, at bogen ikke giver et meget godt overblik over det, som den i øvrigt behandler, nemlig danske kirkefolks forhold til velfærdsstaten og det moderne samfund, og dermed bidrager med konkret historiske materiale, hvad fx Sigrun Kahls studie mangler. Spørgsmålet er, om man kan nå en mere solid konklusion.

Det kan være et problem, at udgivere og forfattere stirrer sig delvist blinde på Kahls tale om betydningen af en konfessions sociale doktriner, og at de på den baggrund ikke mener, at der findes en egentlig evangelisk-luthersk social doktrin, som kan måle sig med fx den ka-

6 Danièle Hervieu-Léger, Religion as a Chain of Memory (Cambridge: Polity Press 2000). 
tolske. Dermed udelukkes muligt relevant materiale. Det er langt fra sikkert, at der går en direkte linje fra en eksplicit teologisk sociallære til konkrete socialpolitiske virkninger. Leder man efter direkte forbindelse overser man, at selve den teologiske kerne i fx lutherdommen kan udfoldes som en sociallære. Med andre ord den lutherske teologi har ikke en sociallære, den er en sociallære. Det er den, fordi den i vid udstrækning forstår gudsforholdet i sociale kategorier: synd er udelukkelse fra fællesskabet med Gud, retfærdiggørelse er genetablering af det brudte fællesskab.

Udgiverne afviser ikke enhver sammenhæng mellem lutherdom og velfærdssamfund, men ser den snarere knyttet til kirken som institution end til en specifik social doktrin. Men der er, som antydet, en tredje forbindelsesmulighed, som ikke må overses, nemlig den kristendom, som kirkegængere og konfirmander har lært gennem bl.a. salmer og Den lille Katekismus, og som har formet den konfessionsbestemte baggrundskultur. Niels Kærgaard er en smule inde på det i sit kapitel om sociale holdninger i Den Danske Salmebog, men her synes der at være betydeligt mere at sige, især hvis fokus netop ikke begrænses til det specifikt sociale, men også inddrager mere teologisk kernestof.

Noget entydigt resultat vil man dog næppe nå, for lutherdommen er selv kompleks og peger i flere retninger. Det fremgår tydeligt, når man sammenholder de fine bidrag af Kurt E. Larsen, Liselotte Malmgart, Kim Arne Pedersen og Torben Bramming om henholdsvis Indre Mission, de kirkelige sociale organisationer, grundtvigianisme og Tidehverv. Variationen peger på, at en behandling af Lutherdommens forhold til velfærdsstaten ikke kan komme uden om Lutherdommens egne indbyggede tvetydigheder. 